\title{
Key Events in the Life of the Historical Jesus
}

\author{
A Collaborative Exploration of Context and Coherence \\ Ed. by Darrell L. Bock and Robert L. Webb
}

[Schlüsselereignisse im Leben des historischen Jesu. Untersuchungen zu deren Kontext und Kohärenz.]

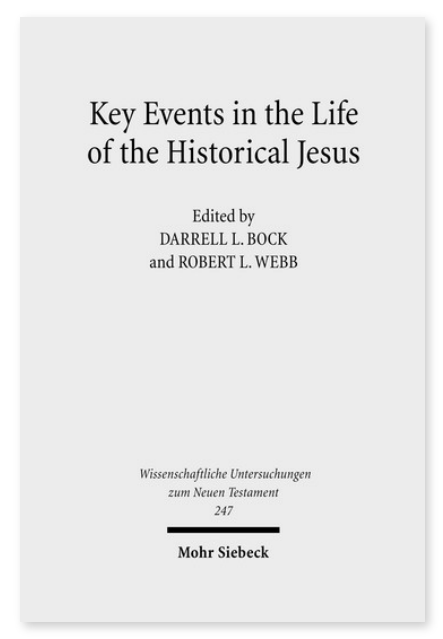

2009. XVII, 931 Seiten. WUNTI 247

ISBN 978-3-16-151536-1

DOI 10.1628/978-3-16-151536-1

eBook PDF 219,00€

ISBN 978-3-16-150144-9

Leinen $219,00 €$
Veröffentlicht auf Englisch.

Die hier gesammelten Beiträge sind das Ergebnis eines Jahrzehnte umfassenden gemeinsamen Forschungsprojektes, in dem die Autoren unter Verwendung eines sorgfältig ausgearbeiteten Ansatzes, der sich der Leben-Jesu-Forschung und der historischen Methode annähert, zwölf Schlüsselereignisse im Leben Jesu analysierten. In jedem Beitrag wird zunächst die Authentizität des jeweiligen Ereignisses untersucht, bevor der entsprechende soziale und kulturelle Hintergrund herausgearbeitet wird, um so ein Bewusstsein für seine historische Bedeutsamkeit zu schaffen. Die ersten sechs Ereignisse stehen mit dem Predigeramt Jesu in Zusammenhang, hauptsächlich mit seinen Aufgaben in Galiläa, die folgenden sechs finden in seinen letzten Tagen in Jerusalem statt. Der letzte Beitrag fasst schließlich zusammen, wie diese Ereignisse möglicher Weise in Zusammenhang stehen und was sie uns über das Wirken Jesu mitteilen.

\section{Inhaltsübersicht}

Darre/l L. Bock/Robert L. Webb: Introduction to Key Events and Actions in the Life of the Historical Jesus - Robert L. Webb: The Historical Enterprise and Historical Jesus Research - Robert L. Webb: Jesus' Baptism by John: Its Historicity and Significance Craig A. Evans: Exorcisms and the Kingdom: Inaugurating the Kingdom of God and Defeating the Kingdom of Satan - Scot McKnight: Jesus and the Twelve - Craig L. Blomberg: The Authenticity and Significance of Jesus' Table Fellowship with Sinners - Donald A. Hagner: Jesus and the Synoptic Sabbath Controversies - MichaelJ. Wilkins: Peter's Declaration concerning Jesus' Identity in Caesarea Philippi - Brent Kinman: Jesus' Royal Entry into Jerusalem - Klyne R. Snodgrass: The Temple Incident - I. Howard Marshall: The Last Supper - Darrell L. Bock: Blasphemy and the Jewish Examination of Jesus - Robert L. Webb: The Roman Examination and Crucifixion of Jesus: Their Historicity and Implications - Grant R. Osborne: Jesus' Empty Tomb and His Appearance in Jerusalem - Darrel/ L. Bock: Key Events in the Life of the Historical Jesus: A Summary

Darrell L. Bock Born 1953; 1979 Master of Theology; 1983 Ph.D. in New Testament Studies; 1995-96 Alexander von Humboldt scholar at the University of Tübingen; since 1982 Professor at Dallas Theological Seminary; since 1996 Research Professor of New Testament Studies at Dallas Theological Seminary.

Robert L. Webb Keine aktuellen Daten verfügbar.

Jetzt bestellen:

https://mohrsiebeck.com/buch/key-events-in-the-life-of-the-historical-jesus-9783161515361?no_cache=1

order@mohrsiebeck.com

Telefon: +49 (0)7071-923-17

Telefax: +49(0)7071-51104 